\title{
Discrepancies in European Union Funding across member nations and sectors as of 2019
}

\author{
Angel-Cristian OLTEŢEANU \\ Bucharest University of Economic Studies, Bucharest, Romania \\ angeloolteteanu@gmail.com
}

\begin{abstract}
This paper aims to explore the discrepancies in attracting European Union funding across member states and across different sectors of activity. Specifically, it aims to discover if there is a set of rule or model that can be attributed to the structure of European Union funding across nations and sectors to discern if some sectors are much more lucrative from the point of attracting European Union funding than others. In addition, beyond the purely economic and business considerations, the article wants to investigate if some ideologies, regimes, or parties are more successful in general in attracting European Union funding by sharing membership between European international parties or other reasons such as funding majoritarian populist parties to sustain European Union membership. The topic is of recent international economics significance in the context of Brexit and the buildup of Eurosceptic sentiments across the European Union as well as the international polarization between blocks of political power in the global trade war. This topic has been addressed partially before, mostly by journalists but represents a niche novelty in academic studies of International Relations. The methodology used will be both through argumentation of historical and current evidence as well as empiric data collection.
\end{abstract}

Keywords: discrepancies, European Union funding, sectorial differences, strategic sectors, political disparity.

\section{Introduction}

In the context of more Euroscepticism and turbulent polarization of political opinion with regards to the European Union, European funding is a concrete and pragmatical base of analysis from which the future of the European Union can be managed. Indeed, European funding can be strongest element of cohesion for the Union as well as the driver for international integration and the study of discrepancies between industries, sectors, countries and regions is a niche novelty in International Relations study which can explain fund causal allocation as well as provide a wider picture of the larger regional macroinvestment opportunities.

However, European funding should not be taken as an abstract factor in economics, but more of a targeted result mainly in areas of capital accumulation and economic interdependence, mixed with modern ideas of economic convergeance and globalization, as well as an international political and economic instrument for more integration with the world or competion with the rest of the world depending on economic circumstances (Dima et al., 2018).

\section{Literature review}

\section{Structure of fund allocation}

For 2019, the allocated EU budget is estimated at 148 billion euros. This sum represents about $2 \%$ of the combined national government budgets of the 28 member countries ( 7.525 trillion) and is smaller than many of the member states budgets such as those of Austria and Belgium (European Commission, last accessed January 2020).

The budget of the European Union as an administrative supra-national governmental body is small as a ration of the value of the economy, when compared to national government budgets. The sum is at $1 \%$ of the total value of the EU Gross Income in contrast to national budgets which 
represent on average $46 \%$ of the value of a national economy (Ibidem). A key difference between national budgets and European Union funding is that while the national budgets mainly fund public, welfare and military services, the budget of the European Union is mainly concerned with development and investments.

In 2018, the average EU citizen spent 240 euros per year for the European Union, budget, which for a usual year would mean 0.65 cents, or less than one basic unit of currency per year.

When counting the sectorial distribution of funding, the European Union has historically mainly been concerned with farming, In 1985, 70\% of the budget went to farming. This has diminished considerably since in 2018, despite the farming sector still being the single largest investment and large as a proportion, it now only accounted for $37 \%$ of the budget. Spending on farming has been reducing despite the fact that most new members from the former Eastern Block have large sections of their economy based on agriculture. The farming sector is projected to shrink in funding even more in the future, with the European Commission estimating that it will fund less than $30 \%$. In spite of the large amount of funding in proportional terms, it also must be noted that since funding for agriculture goes directly into farms of the member state, a large portion of national budget is liberated to go to other sectors.

Regarding the expenditure on administration, around $7 \%$ of the EU budget is spent on administration, mosty paying the salaries and expenses of around 60000 employees a number which is less than the total staff of some member states. Part of the funds for administration also include translation and interpreting services, a total of $1 \%$ of the budget, which ensures colaboration between citizens and institutions.

Auditng for the European Commission is done by the European Court of Auditors (ECA), which generally considers the European Commission to be a prudent administrator. Another key fact in account checking is that a high proportion of funds, almost $75 \%$, are managed jointly by the European Union and member states due to the nature and interlinkage of institutions.

Regarding the rentability of the project, it is estimated that by 2023 , the return on investments for the 2007-2013 period bill be $274 \%$.

Regional development spending between 2014-2020 was 460 billion euros in fields including: healthcare, private sector jobs, broadband acess, sewage instalations, new opportunities for education.

Some projects may prove to provide better return on investment when spent on a continent basis rather than national due to the increased scalse and benefits. Such is the case of the Galileo, European satelite system. The investment plan for Europe has been another plan which surpassed national borders in terms not only of financial chesion but also in regards to investment and development recovering after the 2007 financial crysis. Also, issues such as migration are beyond the reach and scope of solving by national governments working in solitude.

In regards to international competition, strategic prioritization of some sectors over others means that the European Union as a whole can stay competive, provided that the European Institutions are better administrators than logal businesses which smaller scope (European Commission, January 2020). 


\section{About the European Budget}

The European Union budget is an investment budget, different from a national budgets which are mostly spent on supporting existing infrastructure, salaries, pension and other national service provisions. Another key difference is that it cannot be supplemented through borrowing.

The European Union budget is made through a long-term approach caked the Multiannual Financial Framework which places maximum spending amounts for total expenditure as well as policy areas through a minimum of 5 years planification. The maximum ceiling is also expressed as $1.2 \%$ of the EU GNI for the current period in order to be sustainable.

The latest European budget was formed for the period 2014-2020 with a target of around 1 trillion euros. In terms of financing, the budget is formed from $80 \%$ of custom duties (the rest going to the respective member states), VAT contributions and contributions based on GNI.

The size of the EU budget in terms of GNI ceilings has decreased from $1.25 \%$ in the 1993-1999 planning period to 1\% in the current period. The main pillars for the current period in order of funding are Sustainable Growth and Natural resources (420 billion euros), Economic, social and territorial cohesion (371.4 billion Euros), Competitiveness for growth and jobs (142.1 Billion euros), Administration (69.6 billion Euros) and Global Europe (66.3 billion Euros), for a grand total of 1.087 trillion Euros. In percentage terms, the first pillar makes up for $39 \%$ of the budget while the second and third $34 \%$ and $13 \%$ respectively.

The long-term budget is proposed by the European Commission and then needs to be approved by the European Parliament and then unanimously by Member States. The annual budgets are approved by the European Parliament and a qualified majority in the Council (55\% of member states, the total population of which represents at least $65 \%$ of the European Union population).

The control of the budget is made through the European Parliament, the Council and the European Court of Auditors, the external auditor of European institutions. The European Commission is considered as the steward of the EU budget, reporting through annual documents such as the EU consolidated annual accounts. In order to provide a comparable and understandable financial information across member states, the EU accounts are done according to the Public Sector Accounting Standards (IPSAS) (European Commission, March 2020).

\section{The most recent budget figures, 2019}

The process of creating the budget for every year starts in usually in late Spring, with a draft from the European Commission. For the 2019 budget, the European Commission presented its initial proposal on the $23^{\text {rd }}$ of May 2018. Based on this draft the European Parliament adopted its position on the $4^{\text {th }}$ of September and the European Parliament adopted its position on the $24^{\text {th }}$ of October. The conciliation procedure in which the differences between these 2 positions are addressed ran for 21 days from the $30^{\text {th }}$ of October to the $19^{\text {th }}$ of November, and did not reach an agreement which led the European Commission to bring forward a second proposal.

The approved second proposal consisted of the following budget: 


\begin{tabular}{|c|c|c|}
\hline \multirow[t]{2}{*}{ APPROPRIATIONS BY HEADING } & \multicolumn{2}{|c|}{$\begin{array}{l}\text { Budget } 2019 \\
\text { (nominal change in \% compared to 2018) }\end{array}$} \\
\hline & Commitments & Payments \\
\hline 1. Smart and inclusive growth: & $80,527(+3.9 \%)$ & $67,557(+1.4 \%)$ \\
\hline Competitiveness for growth and jobs & $23,335(+6.1 \%)$ & $20,522(+2.1 \%)$ \\
\hline Economic, social and territorial cohesion & $57,192(+3.0 \%)$ & $47,035(+1.1 \%)$ \\
\hline 2. Sustainable Growth: natural resources & $59,642(+0.7 \%)$ & $57,400(+2.4 \%)$ \\
\hline $\begin{array}{l}\text { Market related expenditure and direct } \\
\text { aids }\end{array}$ & $43,192(-0.1 \%)$ & $43,116(-0.2 \%)$ \\
\hline 3. Security and Citizenship & $3,787(+8.4 \%)$ & $3,527(+18.3 \%)$ \\
\hline 4. Global Europe & $11,319(+12.4 \%)$ & $9,358(+5.1 \%)$ \\
\hline 5. Administration & $9,943(+2.9 \%)$ & $9,945(+2.9 \%)$ \\
\hline Other special Instruments & $577(-17.5 \%)$ & $412(-25.2 \%)$ \\
\hline otal appropriations & $165,795(+3.2 \%)$ & $148,199(+2.4 \%)$ \\
\hline
\end{tabular}

PICBE | 711

Figure 1. European Commission, The EU Budget for 2019

Source: European Commission, The EU Budget for 2019: growth, solidarity and security in Europe and beyond provisional agreement reached, https://ec.europa.eu/commission/presscorner/detail/en/IP_18_6381

The largest part of the 2019 budget was committed to improving the European Union economy, employment and competitiveness, including 3.8 billion Euros for infrastructure networks through the Connecting Europe Facility, as well as 57.2 billion Euros dedicated to economic convergence between member states and regions through the European Structural and Investment funds.

The second largest part of the budget, 59 billion Euros were commited to Europan Union Agriculture while the Administration costs allocated were under 10 billion Euros, a 2.9\% increase from 2018 (European Commission, The EU Budget for 2019).

\section{Specifics of funding}

Structural funds and Cohesion funds are shared between EU and local gov administration. The main programs of the 2014-2020 era and their budgets were: Horizon - 77,03 billion euros, Connecting Europe Facility- 21,94 billion euros and Erasmus+ with 14,8 billion euros. Other important programs covered in this period were Employment and Social Innovation program, LIFE program, Consumer program and Creative Europe (European Commission, January 2020) .

From the point of view of geographical coverage, there are two groups:

1) Program Countries which include the 28 Member States, the European Free Trading Association Countries, European Economic Area -EFTA/EEA (Iceland, Liechtenstein, Norway) and Candidate Countries under the Framework Agreement;

2) Partner Countries which include third countries that contribute financially to the budget of the program and have signed a Memorandum of Understanding covering the issue (Idem). 
Another, channel, the Instrument for Pre-Accession Assistance (IPA II) for EU candidates and potential candidates focuses on creating a better and sustainable situation in areas of political, institutional, legal, administrative, social and economic reforms that eventually align practices with EU standard.

- Neighboring Partner Countries participate in programs defined in the Annual Work Programs gruped into funding regions:

South East Europe: Albania, Bosnia, Herzegovina, FYROM, Montenegro, Serbia, Kosovo through UNSC Resolution 1244/1999.

Eastern Europe and Caucasus: Armenia. Azerbaijan, Belarus, Georgia, Moldova, Russian Federation, Ukraine.

Mediterranean Partner Countries: Algeria, Egypt, Israel, Jordan, Lebanon, Morocco, Palestinian Authority of the West Bank and Gaza Strip, Syria, Tunisia (Idem).

Below, two programs, along with their budget and areas of funding are detailed:

1) Ambient Assisted Living Joint Programs (AAL JP)

Budget: 700 million.

Areas of benefit: Health, Information Technology.

Accessed by Private Sector, Research centers and Academic Institutions.

Operating under Article 185 if the Treaty on the Functioning of the European Union and focuses on information and communication technologies ICT and improving the conditions of older adults. It manifests through funding cross-national projects for SMEs, research organizations and organizations for older adults.

2) COSME (Competitiveness of Enterprises and SMEs)

Budget: 2,3 billion Euros.

Areas of benefit Trade and Commerce, Economic growth and Competitiveness, ITC.

Accessed by Private Sector, Public Sector.

COSME focuses on developing the global competitiveness of European Enterprises. It provides better access to finance, business support services and encourages entrepreneurship. It mostly continues the CIP (Competitiveness and Innovation program) and ensures continuity with initiatives from the EIP (entrepreneurship and Innovation Programs). COSME complements actions by Member States and addresses transnational issues, which through economies of scale can be better addressed in block by the European Union. Some problems include fragmentation in the Single market and adoption of the best practices across all Member States:

- Equity venture for growth to enterprises.

- Enterprise Europe Network: business services centers to provide accessible business support.

- Encourage transnational networks. (European Commission, January 2020).

\section{Results and discussions}

\section{Net beneficiaries}

In the most recent available data at the time of writing the article, the net contributors of the European Union for 2017 were Germany, The United Kingdom, France, Italy, The Netherlands, Austria, Finland, Sweden, Denmark and Ireland). The larges net contributor was Germany, with a contribution of 12.8 billion Euros, followed by the United Kingdom with 7.43 billion Euros. Despite the fact that the European Budget is made on a percentage basis of the GNI of the members, it will indeed significantly reduce it's capacity post-Brexit. 
The net beneficiaries, in terms of total net sums received from the highest to the lowest were Poland, Greece, Romania, Hungary, Portugal, the Czech Republic, Belgium, Luxembourg, Bulgaria, lithuania, Slovakia, Latvia, Estonia, Croatia, Slovenia and Malta.

This situation is normal in the context of all countries paying a fixed percentage of their GNI, resulting in larger economies paying more and poorer countries receiving less. There are are also individiual contracts which allow some rebates as is the case of the United Kingdom, however, the attractivity of a country in terms of business is also vital in terms of accumulating more receival of funds. Another synergizing factor for European Union funding is poverty and agricultural activity, with poorer regions that have a wider agriculture receiving more funds through the funding pillar for agriculture and the funding pillar for economic convergeance.

Poland was the highes net recipient of European funds due to a high level of development of business activity but the very small and very rich Luxembourg and Belgium are also net recipients due to much administrative funding for $\mathrm{EU}$ institutuions such as the European Comission and the European Parliament.

An interesting analysis can be made at a per capita level. The lists shift here with the net contributors in order being the Netherlands, Sweden, Germany, Denmark, the United Kingdom, Austria, Italy, France, Finland, Ireland and Spain. The net recipients in order were Luxembourg, Lithuania, Estonia, Greece, Hungary, Latvia, Portugal, Malta, the Czech Republic, Poland, Bulgaria, Belgium, Slovakia, Romania, Croatia, Slovenia and Cyprus.

In terms of GDP, the contributions were under $0.5 \%$ of GDP with the Netherlands being the biggest contributor ( $0.47 \%$ of its GDP). However, this figure becomes much larger and it can be observed that it is a huge boon to the poorer countries of the European Union due to the higher values received from larger economies, transforming into larger portions of GDP for the smaller economies. As such, Lithuania, Bulgaria and Hungary received between $3 \%$ and $2.5 \%$ of their GDP in 2017. Also, in the next tier of economic size and still very significant, Romania, Poland, Greece, Estonia and Latvia received around 2\% of their GDP in European Union Funding (Kovacevic, 2019).

\section{Regional and global economic alliances}

In addition to the former 28, soon to be 27 member states of the European Union being governed by European Institutions, following European law and adhering to common public or tacit policy collaborations, it must be noted that the European Union, unlike other super powers which are national, consist of members with far reaching influence through sets of economic alliances within the European Union and outside of it (Economic alliances in Europe).

For example, the Visegrad Group of 4 consisting of Czechia, Poland, Hungary and Slovakia, claim to be part of a larger Central-European civilization and seek more local integration between their borders, economies and economic actors. As such, due to a wider colaboration, European projects stretching across the 4 members can be much efficiently coordinated (The Visegrad Group).

Another similarly integrated group into the European Union and also collaboration additionally due to local economic accumulations is the Benelux consisting of 3 members, Belgium, Netherlands and Luxembourg, all members as well of the Schengen area, and European Economic Area. A similar group in the fact that all 3 members are European Union members and strive for better integration due to a transcending economy and historical and cultural links is the Baltic Assembly. Composed of Estonia, Lithuania and Latvia, the group promotes intergovernmental cooperation in addition to the EU collaboration and can see the development in collaboration in areas of new technologies, Internet Technology and more collaboration on the DOI: 10.2478/picbe-2020-0067, pp. 708-716, ISSN 2558-9652| Proceedings of the $14^{\text {th }}$ International Conference on 
link to the Eastern trade line between Russia and Central Europe. Another group of political interest and economic cooperation due to geography, similar culture, language groups, history and economic similarity is the Nordic Council. Formed of 87 members, with $3 \mathrm{Eu}$ members (Denmark,Finland, Sweden) collaborating with 2 other European economies not part of the EU (Norway and Finland) and other areas across the world, can together create spillover effects from European Union funding and local as well as global policies (The Nordic Council).

PICBE | 714

Bulgaria, Greece and Romania are also part of the Black Sea Economic Cooperation, an economic collaboration group comprising 12 members, the other 9 being Albania, Armenia, Azerbaijan, Georgia, Moldova, Russia, Serbia, Turkey and Ukraine. Since this group encompasses the 2 large economies of Russia and Turkey as well as smaller developing states, ramifications from European policies can affect the other members as well or vice-versa (The Black Sea Organization).

An informal case can also be made for the Latin countries of France, Italy, Spain and Portugal and also about the agglomerations of historic economic capital and trade between Germany, Switzerland and the South of Italy.

Lastly, members of the European Union can influence through their cohesion and European Union funded projects other international organizations, such as GUAM (Georgia, Ukraine, Azerbaijan and Moldova). Of special note here is also the losing of influence due to Brexit on the group of Commonwealth Nations.

\section{Discrepancies between member states}

A large gap between member states and funding in member states is represented in the Horzion 2020 project, which saw a large disparity between east and west, north and south, with western and northern countries such as the United Kingdom, Netherlands and Scandinavian countries benefiting much more from research grants and funding than countries such as Romania, Bulgaria, or Poland. In this regard, Poland has launched measures to increase the number of returning scientits and decrease its funding abroad. Another issue in this debate is represented by developed third countries which can attract researchers and funding away from Europe, specifically from Central and East European countries, further widening the disparity between rich and poor and slowing economic convergeance (European Commission, January 2020). targets:

Europe 2020 is a ten-year strategy for inclusive growth which aims to reach 5 main

- 75\% of adults aged 20-64 in employment;

- 3\% of EU GDP invested in research and development;

- energy goals of 20\% more energy from renewables as well 20\% more energy efficiency;

- reduce the rate of school abandonment to below $10 \%$ and ensure that more than $40 \%$ of adults aged 30-34 complete third level education;

- reduce the the number of people in risk of poverty and social exclusion by 20 million;

Cohesion policy budget is 351,8 billion euros, $32,5 \%$ of the total EU $2014-2020$ budget.

\section{Political and economic situation}

The heavyweight members of the European Union after Brexit will continue to be Germany and France, respectively in terms of size of their economies, net European funding spending and membership count in the European Parliament. Where European funding is concerned, from the outisde it may seem that funds have been allocated quite generally to member states based on specific economic initiatives. One factor for this neutrality is the long term (10 year strategies) for European funding plans which transcends the government and presidency of a specific party in a DOI: 10.2478/picbe-2020-0067, pp. 708-716, ISSN 2558-9652| Proceedings of the $14^{\text {th }}$ International Conference on 
country as well as one mandate of the European Members of parliament. Indeed, in countries with 2 strong, competing parties, that change sistematically between each other in government, funding cannot be targeted to the government of one specific party because the initiative must be continued by the opposing party. However, this only accounts for national party elections.

In terms of local elections, the same parties usually win for more than one mandate in a row and politically seek to attract national and European funding towards their region. However, where international politics is concerned, the EU may step in and limit funding opportunities, as has recently been the case in the threatened funding sanctions around Poland's international political approach (European Commission, January 2020).

Indeed, Poland and Hungary are interesting cases of growing Euroscepticism in spite of the standard of living of their citizens aproving considerably due to the countries being net beneficiaries of European funding and champions of European funding attraction and successful absorbtion. The figure below shows a detailed breakdown of European Funding by country in terms of total amount of funds and European Structural and Investment funds respectively commited per country.

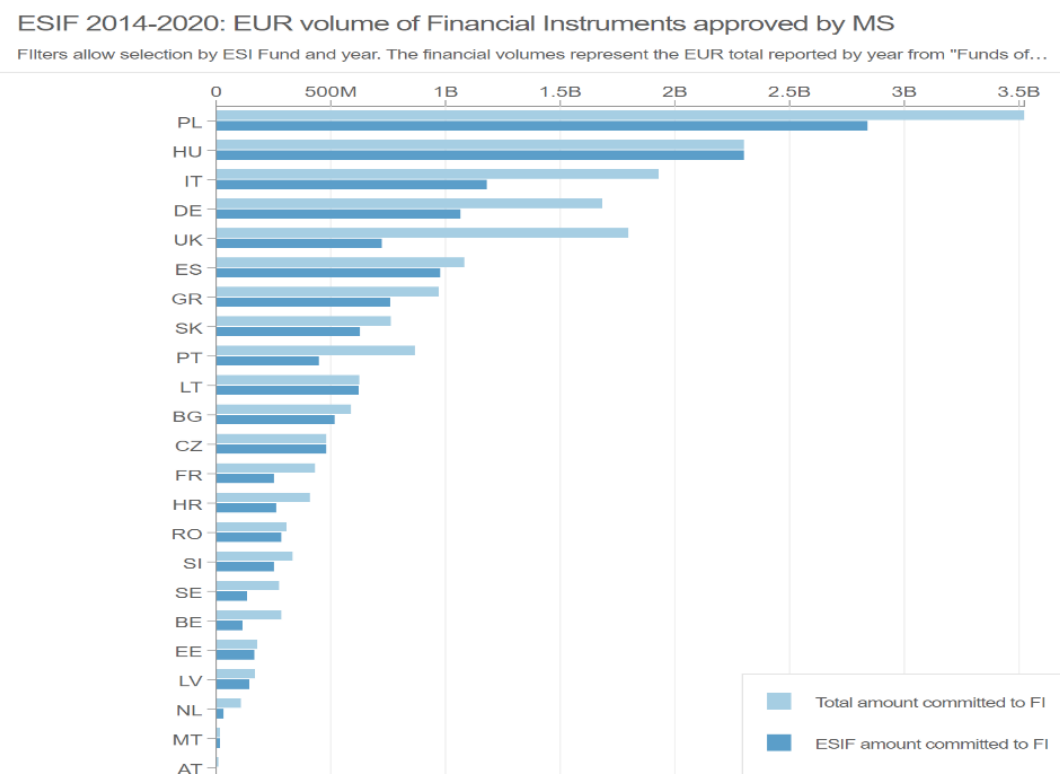

Figure 2. Financial Instruments in Cohesion Policy

Source: European Commission, https://ec.europa.eu/regional_policy/en/funding/financial-instruments/, last accessed January 2020.

Indeed, from the data we can see that the within the main 5 receipients of funds, with the exception of Italy and Germany, the champions of fund attraction are becoming more Eurosceptic, with the United Kingdom having already left the EU. Countries much lower on the list of European fund attraction such as France and Romania have a wider acceptance for proEuropean ideas, in spite of lower rate of fund attraction.

\section{Conclusion}

The field of studying discrepancies in European Union convergent developing and much more to aniche, the study of discrepancies in funding across countries, areas and industries is a niche novelty in International Relations which at present reveals interesting insights and could provide benefits on further investigations. With the withdrawal of the United Kingdom from the European Union earlier this year, cohesion must be strengthened between member states and a large gap of DOI: 10.2478/picbe-2020-0067, pp. 708-716, ISSN 2558-9652| Proceedings of the $14^{\text {th }}$ International Conference on 
funding and distribution of funds will need to be covered, potentially creating an opportunity for fund channel reorganization. This opportunity can be tapped for further cohesion and a more equal distribution albeit potentially reducing global competitiveness; or a more unequal distribution towards countries, sectors and industries which have profitable champions, albeit with the risk of creating further citizen polarization in the European Union and more Euroscepticism.

\section{References}

Dima, A.M., Begu, L., Vasilescu, M.D., \& Maassen, M.A. (2018). The relationship between the knowledge economy and global competitiveness in the European Union. Sustainability, $10,176$.

Economic alliances in Europe, https://business.gov.nl/coming-to-the-netherlands/living-in-thenetherlands/economic-alliances-in-europe/

European Commission, Integrated Financial Reporting Package, https://ec.europa.eu/budget/library/biblio/media/2017/2017_IFRP_brochure_web_final.pd $\mathrm{f}$, last accessed March 2020.

European Commission, online source, Fact check on the EU Budget, https://ec.europa.eu/info/strategy/eu-budget/how-it-works/fact-check_en, last accessed January 2020.

Deloitte, A quick guide to EU funding 2014-2020, online publication, https://www2.deloitte.com/content/dam/Deloitte/cy/Documents/finance/CY_Finance_EU Funding2014-2020Guide_Noexp.pdf last accessed January 2019.

DW, Poland's judicial reforms put EU membership at risk, warns top court, online source:

https://www.dw.com/en/polands-judicial-reforms-put-eu-membership-at-risk-warns-top-court/a51711735 , accessed January $25^{\text {th }} 2020$.

Kovacevic, T. (2019). EU budget: Who pays most in and who gets most back?. Available at BBC News, URL: https://www.bbc.com/news/uk-politics-48256318.

Science Business, online publication: https://sciencebusiness.net/international-news/eu-membersdebate-whether-and-how-much-open-horizon-world, last accessed January 2020.

The Black Sea Organization, http://www.bsec-organization.org/bsec-at-glance

The Nordic Council, https://www.norden.org/en/nordic-council

The Visegrad Group, http://www.visegradgroup.eu/about). 